\author{
Andrzej Tokarski \\ Wyższa Szkoła Bankowa \\ w Toruniu
}

\title{
Upadłość jako naturalny regulator konkurencji i przedsiębiorczości w gospodarce rynkowej na przykładzie gospodarki polskiej
}

Upadłość jest najbardziej drastycznym sposobem zakańczania działalności gospodarczej i przeprowadzana jest wtedy, gdy majątek zadłużonego przedsiębiorstwa nie wystarcza na pokrycie wszystkich ciążących na nim zobowiązań. W przeciwieństwie do innych form zaprzestawania działalności gospodarczej upadłość nie ma cech dobrowolności, lecz jest ustawowym obowiązkiem przedsiębiorstwa, które trwale utraciło zdolność regulowania swoich zobowiązań (Dorozik 2006).

Dzięki procesowi upadłości eliminuje się z gospodarki te przedsiębiorstwa, które nie rokują nadziei na dalsze efektywne funkcjonowanie, co prowadzi do lepszej alokacji środków produkcji. Zmienność i złożoność otoczenia powodują, że ryzyko upadłości należy rozpatrywać w kategoriach zjawiska towarzyszącego działalności każdej jednostki gospodarczej, przy czym prawdopodobieństwo upadłości poszczególnych jednostek gospodarczych jest różne. W gospodarce rynkowej nie ma pewności, że działalność gospodarcza prowadzona przez przedsiębiorstwo przyniesie sukces rynkowy. Dlatego zjawisko upadłości przedsiębiorstw jest swego rodzaju naturalnym regulatorem w systemie ekonomicznym, powodującym zamianę zasobów na bardziej użyteczne drogą zanikania przedsiębiorstw, które nie są efektywne i nie wytrzymują konkurencji (Appenzeller 1998).

\section{Symptomy upadłości przedsiębiorstwa}

Badania prowadzone $\mathrm{w}$ rozwiniętych gospodarkach rynkowych wykazały, że upadłość nie pojawia się w przedsiębiorstwie nagle, lecz niektóre jej symptomy można wykryć nawet ze znacznym wyprzedzeniem. Dzięki temu przedsiębiorstwa mają szansę na podjęcie odpowiednich działań mających na celu ochronę przed przymusową likwidacją. W związku z tym niezwykle ważne staje się poznanie przyczyn, które doprowadzić mogą do upadłości (Hadasik 1998).

Ludzie tłumaczą często swe niepowodzenia i porażki życiowe tym, że nie sprzyja im los, takie jest ich przeznaczenie lub interweniowały osoby trzecie. Niektórzy upatrują winy w sobie, we własnych zaniedbaniach, niedoskonałościach. Przyczyna niepowodzeń leży właśnie w nas, gdyż nie umiemy przewidzieć rozwoju sytuacji oraz sprostać wymaganiom życiowym (Kuciński, Mączyńska 2005).

Aby uniknąć bankructwa lub ograniczyć jego ryzyko, a przynajmniej być na nie przygotowanym, warto wiedzieć, gdzie tkwią jego przyczyny i jaki mają one charakter. Jest to ważne również i z tego powodu, że bankructwo bankructwu nierówne.

Ogólnie symptom można zdefiniować jako pewien zewnętrzny sygnał wskazujący na pogorszenie się sytuacji lub możliwość pojawienia się niekorzystnego zjawiska. Symptomy upadku przedsiębiorstwa można podzielić na (Stasiewski 1995): 
- symptomy finansowe,

- symptomy niefinansowe.

Istotną rolę w rozpoznawaniu symptomów zagrożenia sytuacji finansowej przedsiębiorstwa ma odpowiedni, dostosowany do jego potrzeb, system informacji ekonomicznej, a szczególnie rachunkowości zarządczej i analizy finansowej.

Symptomami finansowymi pogarszającej się sytuacji przedsiębiorstwa mogą być w szczególności (Bednarski 1998a):

- niski poziom wskaźników płynności finansowej i związane z tym pogłębianie braku pokrycia finansowego (wypłacalności) - często wiążące się ze wzrostem należności trudno ściągalnych,

- znaczące zmniejszenie się kwoty zysku brutto (a także netto) lub powstanie straty netto, a także pogorszenie się poziomu podstawowych wskaźników rentowności (sprzedaży, majątku, kapitału własnego),

- przewaga wpływu czynników ekstensywnych nad intensywnymi, powtarzająca się w ocenie przyczynowej przychodów ze sprzedaży i wyniku finansowego,

- widoczne powiększenie się zapotrzebowania na kredyty i pożyczki (zwykle krótkoterminowe) oraz zakłócenia w ich spłacie,

- zwiększanie się zobowiązań wobec dostawców i instytucji publiczno-prawnych, w tym przeterminowanych (mimo stosowanych sankcji),

- zwiększenie się kosztów operacji finansowych, a zwłaszcza płaconych odsetek,

- pozyskiwanie środków na finansowanie bieżącej działalności przez dyskonto weksli i papierów wartościowych oraz niekiedy wyprzedaż składników majątku trwałego po niższej cenie,

- rosnące zamrożenie środków w inwestycjach niezakończonych w terminie,

- wzrost stanu produkcji niezakończonej oraz zapasów wyrobów (towarów) trudno zbywalnych, występowanie przeterminowanych zapasów materiałowych i ich wadliwa struktura. Wśród symptomów pozafinansowych (operacyjnych) zagrożenia sytuacji finansowej przedsiębiorstwa na szczególną uwagę zasługiwać mogą (Bednarski 1998b):

- brak przyszłościowych, realnych planów rozwoju przedsiębiorstwa, ograniczona ilość własnych patentów i zakupionych licencji możliwych do wykorzystania,

- częste zmiany na stanowiskach kierowniczych w przedsiębiorstwie, brak odpowiednio wykwalifikowanej i kompetentnej kadry rezerwowej, a także zachowania i styl życia członków zarządu firmy,

- brak odpowiednio zorganizowanej i spełniającej swe funkcje kontroli wewnętrznej,

- malejący relatywnie udział przedsiębiorstwa w ogólnej sprzedaży na rynku,

- niekorzystna struktura wiekowa maszyn i urządzeń oraz zaniedbania w ich konserwacji i szkodliwość dla środowiska,

- utrata najważniejszych odbiorców i rzetelnych finansowo klientów lub korzystnych źródeł dostaw,

- znaczne zwolnienia pracowników, zmniejszenie efektywnego czasu pracy oraz ograniczenie świadczeń socjalnych.

Symptomy upadłości klasyfikuje się także według sfer, w których występują. Wówczas wyróżnić można (Zelek 2003):

- zarządzanie operatywne (nadmierne zapasy, niedostatek kapitału, złe kierowanie ludźmi, nadmierne zadłużenie, niefachowa księgowość, brak zawodowych umiejętności, nieoszacowanie kosztów, zawyżenie dochodów,

- strategia (brak popytu na produkty, zawiązanie niewłaściwej spółki, brak przeciwdziałania konkurencji, uzależnienie od niewielu klientów i dostawców), 
- technologie (niedopracowany produkt, zastosowanie wadliwych materiałów, niedostatek wiedzy, doświadczenia),

- koszty (wzrost kosztów materiałowych, wzrost kosztów wytwarzania, wzrost kosztów ogólnych, wzrost kosztów stałych, wzrost płac),

- marketing (niewłaściwe prognozy, przereklamowanie, zawyżanie cen, zaniżanie cen),

- management (zbyt wysokie wynagrodzenia kadry kierowniczej, zły stan zdrowia kluczowych osób, waśnie między wspólnikami).

B. Nogalski, H. Mocinkiewicz (2004) uważają, iż upadłość jest ostatnią fazą kryzysu, przy czym wymieniają bardzo wiele podstawowych przyczyn upadłości. Do symptomów upadłości przedsiębiorstwa zaliczają negatywne zjawiska występujące w następujących obszarach działalności:

I. czynniki zewnętrzne (niewłaściwe relacje z bankami, dostawcami, klientami, audytorem i doradcą podatkowym, władzami (urzędami) przejawiające się wzrostem liczby wniosków o odroczenie zapłaty podatków oraz zwiększeniem zainteresowania subwencjami, spadkiem wykorzystania możliwości roszczeń);

II. czynniki wewnętrzne (w obszarze zarządzania, w zakresie zarządzania ludźmi, w obszarze organizacji, produkcji, logistyki i zaopatrzenia, badań i rozwoju, a także w zakresie inwestycji, finansów, kontrolingu i planowania.

Można więc zauważyć, że istnieje wiele symptomów, które pozwalają wskazać, czy dane przedsiębiorstwo jest zagrożone upadłością, czy nie.

\section{Upadłość przedsiębiorstw w Polsce - dynamika i struktura}

Wprowadzenie zasad gospodarki rynkowej w Polsce przywróciło właściwą rolę postępowaniu upadłościowemu przedsiębiorstw (Boniecki 2006).

Upadłość zaistniała w Polsce jako nowy, ważny element życia gospodarczego dopiero po roku 1989 (Matuszak 2001). Było to skutkiem wprowadzenia ustawy o działalności gospodarczej. Fala lawinowo narastających upadłości zaczęła się w Polsce w 1991 r. Wtedy to właśnie, w wyniku liberalizacji reguł wejścia, gwałtownie wzrosła liczba funkcjonujących w gospodarce przedsiębiorców. Z drugiej jednak strony zasady gospodarki rynkowej doprowadziły do weryfikacji efektywności funkcjonowania przedsiębiorców. Upadać zaczęły nie tylko młode i nieprzystosowane przedsiębiorstwa, ale także duże zakłady z wieloletnią tradycją i unormowaną pozycją. Przyczyną tego zjawiska było niedostrzeżenie w porę nadchodzącego kryzysu i niewprowadzenie niezbędnych zmian, które pozwoliłyby na dostosowanie się do warunków gospodarki rynkowej (Sudoł 2001).

Dane statystyczne, dotyczące podmiotów w całej gospodarce i obejmujące okres od początku transformacji, wskazują na niską odporność podmiotów gospodarczych na pojawiające się bariery rynkowe, wahania koniunkturalne i szoki zewnętrzne (Belka 2001). Było to zresztą podstawą tezy o występowaniu w naszej gospodarce quasi-cyklu koniunkturalnego. Poziom aktywności gospodarczej po 1989 r. można podzielić na następujące fazy (Mączyńska 2004):

- 1990-1992 - recesja transformacyjna,

- 1992-1994 - wczesne ożywienie,

- 1994-1998 - przyspieszenie,

- 1998-2003 - osłabienie koniunktury przy znacznej jej wahliwości,

- 2004-2008 - przyspieszenie związane z ożywieniem gospodarczym

- 2009 - osłabienie koniunktury związane z globalnym kryzysem światowym.

W Polsce oficjalnie publikowane i powszechnie dostępne dane dotyczące zjawiska obejmują jedynie liczbę złożonych wniosków o upadłość oraz ich układ. Informacje te są opracowywane przez Ministerstwo Sprawiedliwości i publikowane na jego stronach internetowych. 
Dane ewidencyjne wskazują na ogromny, wręcz skokowy wzrost spraw upadłościowych w latach 1991-1992. O ile w 1990 r. do sądu wpłynęło jedynie 149 takich spraw, to w roku 1991 już 1250, a w 1992 - aż 3661. Największą ich liczbę zanotowano w sądach województw: warszawskiego (438 spraw), gdańskiego (271), łódzkiego (232), katowickiego (231) i poznańskiego (204). Nadmienić należy, że wnioski do sądu składali przede wszystkim dłużnicy, przy czym w 1991 r. zweryfikowano pozytywnie 45,3\% zgłoszonych wniosków, a w 1992 r. - zaledwie 37,8\%. Z informacji uzyskanych z sądów wynika, że najwięcej upadłości dotyczyło spółek, a następnie przedsiębiorstw państwowych i spółdzielni (Patologie w bankructwach 1993).

W okresie od 1993 do końca 2002 r. zanotowano kolejny wzrost liczby upadłości (Michałków 2005). Niemal we wszystkich sektorach gospodarki zauważono poważny spadek przeciętnej rentowności. Polskim przedsiębiorstwom dokuczały: brak kapitału, narastająca presja konkurencji, zatory płatnicze i bardzo niesprzyjające środowisko makroekonomiczne. W latach 1990-2002 liczba upadłości podwoiła się, gdyż wzrosła z poziomu około $3000 \mathrm{w} 1999 \mathrm{r}$. do około 7000 trzy lata później (Korol 2008).

Wyjątkowo trudnym i niekorzystnym okresem dla przedsiębiorstw w Polsce był rok 2002 (Nowara, Szarzec 2004). Prawie 40\% przedsiębiorstw wykazywało straty. Znaczną część przedsiębiorstw cechował ujemny kapitał własny - oczywisty symptom zagrożenia bankructwem.

Upadłość zaczęła także nękać spółki notowane na Giełdzie Papierów Wartościowych w Warszawie. Do końca sierpnia 2003 r. sądy ogłosiły upadłość dziewięciu spółek publicznych - Betonstal SA, Espebepe SA, Leta SA, Łukbut SA, Mostostal Gdańsk SA, Ocean SA, Pażur SA, STGroup SA, GK Incest SA (www.coface.pl).

Analizując dane o upadłości polskich przedsiębiorstw z lat 2002-2009, opracowane przez firmę Coface Poland w ujęciu kwartalnym, można zauważyć, iż w latach 2002-2008 upadłość przedsiębiorstw w Polsce wykazywała tendencję malejącą, przy czym w 2009 r., wraz z globalnym kryzysem, zaczęła wykazywać tendencję rosnącą. W poszczególnych latach I kwartału liczba ogłoszonych upadłości kształtowała się następująco ${ }^{1}$ :

- I kwartał 2002 roku - 497 upadłości,

- I kwartał 2003 roku - 480 upadłości,

- I kwartał 2004 roku - 321 upadłości,

- I kwartał 2005 roku - 216 upadłości,

- I kwartał 2006 roku - 154 upadłości,

- I kwartał 2007 roku - 112 upadłości,

- I kwartał 2008 roku - 101 upadłości,

- I kwartał 2009 roku - 126 upadłości.

Postanowienia upadłościowe w Polsce w pierwszych kwartałach w latach 2002-2009 przedstawia rycina 1 .

W ciagu pierwszych trzech miesięcy 2009 r. sądy ogłosiły 126 postanowień o upadłości polskich firm, co wskazuje na wzrost o blisko $25 \%$ wobec I kwartału ubiegłego roku. To oznacza załamanie pozytywnej tendencji spadkowej, która utrzymywała się niezmiennie od 2002 r. Dane za cały 2008 r. pokazywały jeszcze ośmioprocentowy spadek liczby upadłości w stosunku do 2007 roku. Liczbę upadłości przedsiębiorstw w I kwartałach 2007-2009 przedstawia tabela 1 .

\footnotetext{
${ }^{1}$ Coface podaje petne dane na temat upadtości firm w I kwartale 2009 r. Koniec tendencji spadkowej stat się faktem! - www.coface.pl. Firma Coface dla zachowania porównywalności danych ukazała liczbę upadłości polskich przedsiębiorstw w I kwartale 2002-2009.
} 
Ryc. 1. Postanowienia upadłościowe w Polsce w pierwszych kwartałach w latach 2002-2009

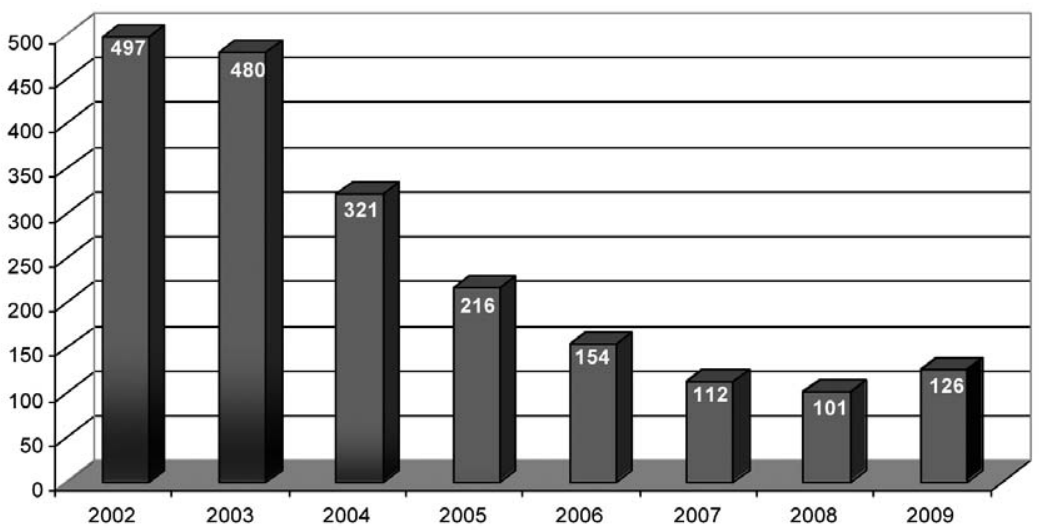

Źródło: www.coface.pl

Tab. 1. Liczba i rodzaj postępowania upadłościowego - analiza porównawcza I kwartałów lat 2007-2009

\begin{tabular}{|l|c|c|c|c|c|}
\hline \multicolumn{1}{|c|}{$\begin{array}{c}\text { Rodzaj postępowania } \\
\text { upadłościowego }\end{array}$} & $\begin{array}{c}\text { I kwartal } \\
\mathbf{2 0 0 7}\end{array}$ & $\begin{array}{c}\text { zmiana } \\
\mathbf{2 0 0 7 / 0 8}\end{array}$ & $\begin{array}{c}\text { I kwartal } \\
\mathbf{2 0 0 8}\end{array}$ & $\begin{array}{c}\text { zmiana } \\
\mathbf{2 0 0 8 / 0 9}\end{array}$ & $\begin{array}{c}\text { I kwartal } \\
\mathbf{2 0 0 9}\end{array}$ \\
\hline $\begin{array}{l}\text { Upadłości w celu likwidacji } \\
\text { majątku }\end{array}$ & 94 & & 81 & & 102 \\
\hline $\begin{array}{l}\text { Upadłości z możliwością zawarcia } \\
\text { układu }\end{array}$ & 18 & & 20 & & 24 \\
\hline Ogółem & 112 & $-9,8 \%$ & 101 & $+243 \%$ & 136 \\
\hline
\end{tabular}

Źródło: www.coface.pl

W statystykach upadłości ogłoszonych w 2009 r. pojawiają się już firmy, na których niewypłacalność bezpośredni wpływ miały czynniki wynikające z kryzysu (www.coface.pl). W wielu sektorach drastyczny spadek liczby zamówień, spowodowany zmniejszonym popytem zewnętrznym oraz wewnętrznym, doprowadził do spadku poziomu sprzedaży, zmniejszenia produkcji i ograniczenia współpracy z kooperantami, a w rezultacie pogorszenia dyscypliny płatniczej w całym łańcuchu dostawców i odbiorców. Pojawiają się zatory płatnicze, które bezpośrednio wpływają na problemy przedsiębiorstw z płynnością, co staje się główną przyczyną upadłości. Tabela 2 przedstawia analizę branżową liczby upadłości w I kwartałach 2008 i 2009.

Analizując dane branżowe, można zauważyć, iż odnotowano zdecydowany wzrost upadłości wśród przedsiębiorstw transportowych (13 firm, podczas gdy rok temu ogłoszono jedno bankructwo, a w ostatnim kwartale 2008 - cztery). Zauważalny jest także wzrost liczby upadłości firm handlowych, działających zarówno w handlu hurtowym, jak i detalicznym (32 wobec 17 w I kwartale 2008 oraz 21 w IV kwartale 2008). Statystyki potwierdzają także złą kondycję branży stalowej (10 bankructw wobec pięciu rok temu oraz trzy w poprzednim kwartale). 
Tab. 2. Liczba upadłości w branżach w I kwartałach 2008-2009

\begin{tabular}{|l|c|c|}
\hline \multicolumn{1}{|c|}{ Branża } & $\begin{array}{c}\text { Liczba upadłości } \\
\text { I kwartal 2008 }\end{array}$ & $\begin{array}{c}\text { Liczba upadłości } \\
\text { I kwartal 2009 }\end{array}$ \\
\hline Przetwórstwo przemysłowe, w tym: & 47 & 55 \\
\hline produkcja artykułów spożywczych i napojów & 10 & 12 \\
\hline produkcja odzieży i wyrobów tekstylnych & 7 & 6 \\
\hline produkcja metali i metalowych wyrobów gotowych & 5 & 10 \\
\hline produkcja pozostała & 25 & 27 \\
\hline Handel, w tym m.in.: & 17 & 32 \\
\hline handel hurtowy & 16 & 22 \\
\hline handel detaliczny & 0 & 7 \\
\hline Transport i gospodarka magazynowa & 1 & 13 \\
\hline Budownictwo & 19 & 12 \\
\hline Działalność związana z obsługą rynku nieruchomości & 0 & 3 \\
\hline Pozostałe branże & 17 & 11 \\
\hline Ogółem & 101 & 126 \\
\hline Zmiana & & $+24,8 \%$ \\
\hline
\end{tabular}

Źródło: www.coface.pl

Procentowa struktura upadłości przedsiębiorstw w I kwartale 2009 roku według branży przedstawiała się następująco:

- produkcja - 44\%,

- handel-25\%,

- transport i logistyka - 10\%,

- budownictwo - 10\%,

- pozostałe $-11 \%$.

Procentową strukturę upadłości przedsiębiorstw w I kwartale 2009 roku według branży przedstawia rycina 2 .

Ryc. 2. Procentowa struktura upadłości według branży

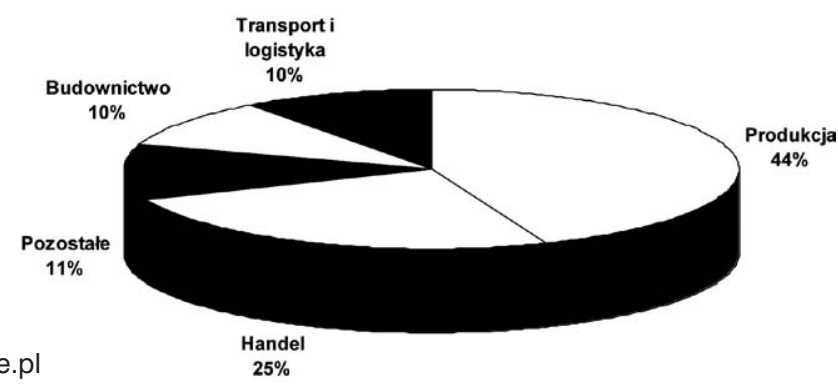

Źródło: www.coface.pl 
Przy analizowaniu liczby upadłości w poszczególnych regionach szczególną uwagę zwraca istotna zmiana na czołowych pozycjach. Tabela 3 ukazuje liczbę upadłości przedsiębiorstw w I kwartale 2008 i 2009 w poszczególnych województwach.

Tab. 3. Liczba upadłości przedsiębiorstw w I kwartale 2008 i 2009 - analiza regionalna

\begin{tabular}{|l|c|c|c|}
\hline \multicolumn{1}{|c|}{ Województwo } & $\begin{array}{c}\text { Liczba upadłości } \\
\text { I kwartal 2008 }\end{array}$ & $\begin{array}{c}\text { Liczba upadłości } \\
\text { I kwartal 2009 }\end{array}$ & Zmiana \\
\hline Mazowieckie & 17 & 24 & $+41 \%$ \\
\hline Dolnośląskie & 9 & 16 & $+78 \%$ \\
\hline Śląskie & 22 & 15 & $-32 \%$ \\
\hline Zachodniopomorskie & 11 & 13 & $+18 \%$ \\
\hline Kujawsko-pomorskie & 4 & 9 & $+125 \%$ \\
\hline Małopolskie & 6 & 7 & $+17 \%$ \\
\hline Podkarpackie & 3 & 6 & $+100 \%$ \\
\hline Pomorskie & 4 & 6 & $+50 \%$ \\
\hline Wielkopolskie & 4 & 6 & $+50 \%$ \\
\hline Lubelskie & 6 & 5 & $-17 \%$ \\
\hline Łódzkie & 3 & 5 & $+67 \%$ \\
\hline Lubuskie & 3 & 4 & $+33 \%$ \\
\hline Warmińsko-mazurskie & 4 & 4 & b.z. \\
\hline Opolskie & 0 & 2 & t \\
\hline Podlaskie & 0 & 2 & $+60 \%$ \\
\hline Świętokrzyskie & 5 & 126 & $+24,8 \%$ \\
\hline Ogółem & 101 & & \\
\hline
\end{tabular}

Źródło: www.coface.pl

Od lat na drugim miejscu (zaraz za niezmiennym liderem - Mazowszem) znajdowało się województwo śląskie (www.coface.pl). Taki układ był efektem statystycznym, ponieważ w tych dwóch regionach działa najwięcej podmiotów, więc liczba upadłości odzwierciedlała wprost proporcjonalnie rozwój przedsiębiorczości. Jednak w pierwszym kwartale bieżącego roku zaobserwowano spadek bankructw w województwie śląskim o blisko jedną trzecią i przesunięcie tego regionu na trzecią pozycję. W większości województw sądy ogłosiły więcej upadłości (tylko trzy regiony zanotowały spadek). W dalszym ciagu na pierwszych miejscach znajdują się województwa: dolnośląskie (wzrost aż o 78\%), zachodniopomorskie oraz kujawsko-pomorskie (więcej o pięć bankructw, jednak przy tak małej nominalnej wartości stanowi to przyrost aż o 125\%). Województwa opolskie i podlaskie, które rok wcześniej miały czystą kartę, zanotowały po dwie upadłości. Tabela 4 przedstawia liczbę upadłości przedsiębiorstw według form prawnych przedsiębiorstw. 
Tab. 4. Upadłości według form prawnych przedsiębiorstw

\begin{tabular}{|l|c|c|}
\hline \multicolumn{1}{|c|}{ Forma prawna } & $\begin{array}{c}\text { Liczba upadłości I } \\
\text { kwartal 2008 }\end{array}$ & $\begin{array}{c}\text { Liczba upadłości I } \\
\text { kwartal 2009 }\end{array}$ \\
\hline Spółka z o.o. & 59 & 78 \\
\hline Przedsiębiorca & 24 & 19 \\
\hline Spółka akcyjna & 7 & 21 \\
\hline Spółka jawna & 3 & 4 \\
\hline Spółdzielnia & 4 & 3 \\
\hline Przedsiębiorstwo państwowe & 2 & 1 \\
\hline Pozostałe formy & 2 & 0 \\
\hline Ogółem & 101 & 126 \\
\hline
\end{tabular}

Źródło: www.coface.pl

Najbardziej widoczną zmianą w analizie upadłości pod kątem form prawnych jest trzykrotny wzrost bankructw spółek akcyjnych. W pierwszym kwartale bieżącego roku upadło 21 takich przedsiębiorstw, co w tej grupie już stanowi trzy czwarte całkowitej liczby z $2008 \mathrm{r}$. W analizowanym okresie stanowiły one 16,5\% wszystkich ogłoszonych w Polsce upadłości, podczas gdy w całym 2008 ich udział kształtował się na poziomie 1,5\%. To wśród spółek akcyjnych znalazło się niestety wiele firm dotkniętych skutkami kryzysu globalnego, jak również następstwem niekorzystnych umów na opcje walutowe (np. Kuźnia Polska SA, Odlewnie Polskie SA, Huta KROSNO SA. czy Fabryka Elektrolitów ELWO SA), ale także zmianami właścicielskimi i restrukturyzacją (np. Stilon Gorzów).

Najwięcej upadłości zanotowano ponownie wśród spółek z ograniczoną odpowiedzialnością. Stanowiły one blisko $62 \%$ wszystkich upadających firm.

\section{Przyczyny upadłości przedsiębiorstw w Polsce}

E. Mączyńska i M. Zawadzki (2004) uważają, że upadłość polskich przedsiębiorstw w okresie transformacji spowodowana była różnymi czynnikami, przy czym miały one charakter sektorowy lub indywidualny, a wynikały zarówno z czynników makroekonomicznych, jak i mikroekonomicznych.

W ujęciu makroekonomicznym lub sektorowym wymienić można takie przyczyny prowadzące do upadłości przedsiębiorstw, jak:

- spadek tempa wzrostu gospodarczego lub, w jeszcze silniejszym stopniu, recesja gospodarcza,

- zanik nieefektywnej wymiany międzynarodowej,

- zmiany kursów walutowych,

- globalizacja działalności gospodarczej i wynikające z niej zagrożenie importem,

- wzrost dochodów ludności ograniczający popyt na wyroby pospolite,

- zanik subsydiowania produkcji określonych wyrobów,

- radykalne zmiany w strukturze popytu będące konsekwencją postępu technicznego, przemian kulturowych lub nawet politycznych, społecznych czy religijnych.

Oddziaływanie czynników makroekonomicznych na sytuację przedsiębiorstw było szczególnie widoczne w krajach przechodzących transformację systemową, także w Polsce. Odnosząc te czynniki do sytuacji Polski, można mówić o oddziaływaniu czynnika sektorowego 
decydującego o upadłości w takich branżach, jak górnictwo, lub niektórych sektorach rolnictwa (warzywnictwo, ogrodnictwo szklarniowe). Znaczną część przedsiębiorstw narażonych na upadłość stanowiły przedsiębiorstwa subsydiowane lub których koszty wytwarzania były zaniżone przez nierealne parametry makroekonomiczne, zazwyczaj niski oficjalny kurs walutowy. Miało to miejsce na przykład w przemyśle elektronicznym (Mączyńska, Zawadzki 2004).

Silnym czynnikiem powodującym radykalne obniżenie popytu na wyroby określonych sektorów było mające na początku lat 90 . XX w. urealnienie poziomu ich cen (wzrostu w stosunku do poziomu dochodów pewnych grup ludności), a także powstania nowych wzorców konsumpcyjnych obniżających wcześniej ukształtowany poziom popytu, (na przykład wiele sektorów należących do przemysł spożywczego). Czynnik popytowy miał zasadnicze znaczenie $\mathrm{w}$ przypadku przedsiębiorstw obsługujących wielkie sektory infrastrukturalne, głównie PKP.

Druga grupa czynników powodujących upadłość przedsiębiorstw to czynniki indywidualne, które są konsekwencją działania w warunkach konkurencji.

Do pierwotnych przyczyn uniemożliwiających przedsiębiorstwom skuteczne konkurowanie należy zaliczyć wiele ich cech mikroekonomicznych różnorodnej natury. Należą do nich na przykład: niewłaściwa wielkość przedsiębiorstwa, jego zła lokalizacja, niskie kwalifikacje kadry zarządzającej i wykonawczej, brak odpowiedniego know-how i wynikająca z tego niska jakość produktów, brak dostępu do kanałów zbytu, uzależnienie od dostawców, brak doświadczenia, brak znanej marki, brak dostępu do kapitału i wiele innych.

Niska konkurencyjność wyrobów niektórych branż w stosunku do wyrobów pochodzących z importu była przyczyną upadku wielu polskich przedsiębiorstw w takich branżach, jak przemysł elektroniczny (odbiorniki telewizyjne, radiowe, telefony, elementy elektroniczne) lub komputerowy, których wyroby odbiegały od standardów technologicznych stosowanych w wyrobach firm dominujących na rynkach światowych.

Podobnie wyglądała sytuacja przedsiębiorstw w sektorach, w których następował zanik konkurencji typu cenowego. Ten czynnik doprowadził do upadku dość dobrze rozwiniętego w Polsce sektora małych przedsiębiorstw, szczególnie tak zwanej drobnej wytwórczości oferującej tanie produkty niskiej jakości.

W okresie transformacji systemowej częstą przyczyną upadłości było zaniechanie wszelkich działań restrukturyzacyjnych w warunkach silnych zmian otoczenia, szczególnie spadku popytu krajowego.

W wielu przedsiębiorstwach niedostateczna restrukturyzacja wynikała z obiektywnych trudności restrukturyzacji, przestarzałej infrastruktury technicznej (na przykład w przemyśle włókienniczym zakładów powstałych w XIX wieku), a w innych z kolei z nadmiernego zaangażowania się w finansowane kredytami programy inwestycyjne, które utraciły swoje uzasadnienie w konsekwencji zaszłych zmian systemowych.

Upadłość niektórych przedsiębiorstw wynikała także z trudności w znalezieniu consensusu co do kierunków restrukturyzacji i prywatyzacji (akceptowanego przez główne siły społeczne lub zawodowe), a także z błędów organów założycielskich w wyborze sposobu prywatyzacji lub wyborze inwestora strategicznego.

M. Szczerbak (2005) wyszczególniła na podstawie przeprowadzonych badań następujące przyczyny upadłości polskich przedsiębiorstw:

- rynkowe i społeczne - spadek popytu na wyroby przedsiębiorstwa na rynkach krajowych i zagranicznych, rozwój sieci hipermarketów, agresywna konkurencja, wyższe wymagania konsumenckie, silna konkurencja zagraniczna, 
- kapitałowe - ograniczony dostęp do zewnętrznych źródeł, niedobór finansowania własnych środków, wahania kursów walut, wysoki stopień formalizacji i biurokratyzacji procedur uzyskania zewnętrznego dofinansowania, wysoki koszt pozyskania kapitału, brak dofinansowania poprzez zamówienia publiczne,

- wynikające z polityki gospodarczej - niekorzystne regulacje na rynku pracy, a także w sferze ubezpieczeń społecznych, zmniejszenie ulg podatkowych, zwiększenie obciążeń podatkami pośrednimi, skomplikowany i niejasny system podatkowy, wysokie wymagania stawiane przez instytucje ochrony środowiska, liberalizacja importu w ramach UE, liberalizacja importu z obszaru spoza UE,

- wewnętrzne, w sferze operacyjnej - słabości w zarządzaniu, błędna strategia niedokonywania zmian w technologii wytwarzania produktów, niedostosowanie jakości wyrobów do jakości wyrobów konkurencyjnych, niepodjęcie produkcji produktów innowacyjnych, niewykorzystanie przez przedsiębiorstwo potencjalnych możliwości, jakie stwarza zwiększenie skali produkcji, brak dostępu do tańszej siły roboczej, przestarzały oraz zaniedbany park maszynowy, niedostateczne działania marketingowe, brak reklamy, zła organizacja dystrybucji i obsługi posprzedażowej, trudności w zdobyciu odpowiednich materiałów i surowców,

- wewnętrzne o charakterze finansowym - brak odpowiedniej kontroli finansowej, wysoki wskaźnik dźwigni finansowej, zachowawcza polityka finansowa, inwestowanie w długoterminowe projekty, wysokie zadłużenie przedsiębiorstwa, zobowiązania przeterminowane, ułomności w zarządzaniu należnościami, środkami pieniężnymi, trudności w pozyskiwaniu kredytów i pożyczek, ujemny wynik finansowy, kreatywna (agresywna) rachunkowość,

- wewnętrzne - o charakterze wewnątrzorganizacyjnym - niska wydajność pracowników, niedokonanie redukcji pracowników w stosownym czasie, nadmiar pracowników w komórkach administracyjnych, konflikty interpersonalne, brak szkoleń pracowników,

- nieudane przejęcia/fuzje,

- niewlaściwie przeprowadzona prywatyzacja przedsiębiorstw.

Wśród przyczyn niepowodzeń ekonomicznych wyraźnie najwięcej wskazań (22\%) uzyskały czynniki wewnętrzne w sferze operacyjnej, 20\% wskazań dotyczyło czynników wewnętrznych w sferze finansowej, 13\% wskazań to przyczyny o charakterze wewnątrzorganizacyjnym. Małą liczbę wskazań uzyskały przyczyny kapitałowe - 12\%, przyczyny wynikające z polityki gospodarczej - 10\%, przyczyny rynkowe i społeczne na równym poziomie z niewłaściwie przeprowadzoną prywatyzacją przedsiębiorstw - 9\%. Najniżej punktowane były nieudane przejęcia/fuzje - 5\%.

Wyniki badań syndyków i nadzorców sądowych wskazują na duże znaczenie czynników leżących po stronie przedsiębiorstw, czyli czynników wewnętrznych (np. niska jakość pracy, nieumiejętne zachowania menedżerskie). Wynika z tego, że polskie przedsiębiorstwa cechują przestarzałe, nadmiernie rozbudowane struktury, często tworzone pod ludzi, a nie dla wyznaczonego celu.

Należy wspomnieć także o upadłości zamierzonej, która następowała w wielu sytuacjach, na przykład wykupu przedsiębiorstwa w celu zapobieżenia powstania konkurencji, lub możliwości egzystowania wąskiej grupy menagementu w sytuacji ustawowych możliwości zbytu aktywów oraz przeznaczania środków ze sprzedaży na finansowanie bieżącej działalności. Tak więc istnieje szereg czynników o charakterze mikroekonomicznym i makroekonomicznym mających wpływ na upadłość przedsiębiorstw w Polsce. 


\section{Zakończenie}

Kryzys oraz upadłość są zjawiskami charakterystycznymi dla gospodarki rynkowej, których nie da się wyeliminować. Dlatego też należy nauczyć się z nimi funkcjonować, a w zasadzie czynić wszystko, aby do wystąpienia tych zjawisk nie dopuścić. Dzięki procesowi upadłości eliminuje się jednak z gospodarki te przedsiębiorstwa, które nie rokują nadziei na dalsze efektywne funkcjonowanie i prowadzi się do lepszej alokacji środków produkcji.

Zmienność i złożoność otoczenia sprawiają, że ryzyko upadłości należy rozpatrywać w kategoriach zjawiska towarzyszącego działalności każdej jednostki gospodarczej, przy czym prawdopodobieństwo upadłości poszczególnych jednostek gospodarczych jest różne.

W gospodarce rynkowej nie ma pewności, że działalność gospodarcza prowadzona przez przedsiębiorstwo przyniesie sukces rynkowy. Dlatego zjawisko upadłości przedsiębiorstw jest swego rodzaju naturalnym regulatorem w systemie ekonomicznym, który powoduje zamianę zasobów na bardziej użyteczne drogą zanikania przedsiębiorstw, które nie są efektywne i nie wytrzymują konkurencji.

\section{Literatura}

1. Appenzeller D., 1998, Mikro- i makroekonomiczne przyczyny upadłości, „Ruch Prawniczy, Ekonomiczny i Socjologiczny", nr 3-4.

2. Bednarski L., 1998, Problemy oceny zagrożenia sytuacji finansowej przedsiębiorstwa, ZTRN, nr 46.

3. Bednarski L., 1998, Symptomy i metody oceny zagrożenia sytuacji finansowej przedsiębiorstwa [w:] „Zeszyty Naukowe Wyższej Szkoły Administracji i Biznesu w Gdyni”, nr 2.

4. Belka M., 2001, Doświadczenia polskiej transformacji [w:] E. Mączyńska Restrukturyzacja przedsiębiorstw w procesie transformacji gospodarki, DiG, Warszawa.

5. Boniecki M., 2006, Rachunkowość przedsiębiorstw postawionych w stan upadtości, „Problemy rachunkowości”, lipiec-wrzesień 2006.

6. Dorozik L., 2006, Restrukturyzacja ekonomiczna przedsiębiorstw, PWE, Warszawa.

7. Hadasik D., 1998, Upadtość przedsiębiorstw w Polsce i metody jej prognozowania, „Zeszyty Naukowe - Seria II", Prace habilitacyjne, Zeszyt 153, AE Poznań, Poznań.

8. Korol T., 2008, Dynamiczno-statyczny model prognozowania upadłości spółek giełdowych [w:] E. Mączyńska, Bankructwa przedsiębiorstw. Wybrane aspekty instytucjonalne, SGH, Warszawa.

9. Kuciński K., 2005, Powody upadtości przedsiębiorstw [w:] K. Kuciński, E. Mączyńska, Zagrożenie upadłościq, SGH, Warszawa.

10. Matuszak M., 2001, Upadłość polskich przedsiębiorstw w latach 1990-2000. Wybrane problemy $i$ wyniki badań prowadzonych w sqdach gospodarczych [w:] B. Godziszewski, M. Haffer, M.J. Stankiewicz, Przedsiębiorstwo na przełomie wieków, UMK Toruń, Toruń.

11. Mączyńska E., 2004, Globalizacja ryzyka a systemy wczesnego ostrzegania przed upadłościa [w:] D. Appenzeller, Upadtość przedsiębiorstw w Polsce w latach 1990-2003. Teoria i praktyka, AE Poznań.

12. Mączyńska E., Zawadzki M., 2000, Modelowe i prognostyczne aspekty pomiaru zmian w sytuacji przedsiębiorstw $w$ restrukturyzacji - analiza dyskryminacyjna, INE-PAN, Warszawa.

13. Michałków I., 2005, Bankructwa firm w Polsce-ich źródła i struktura [w:] K. Kuciński, E. Mączyńska, Zagrożenie upadłościq, SGH, Warszawa.

14. Nogalski B., Mocinkiewicz H., 2004, Zarzqdzanie antykryzysowe przedsiębiorstwem. Pokonać kryzys $i$ wygrać, Difin, Warszawa. 
15. Nowara W., Szarzec K., 2004, Charakterystyka upadtości polskich przedsiębiorstw - wyniki badań [w:] D. Appenzeller, Upadtość przedsiębiorstw w Polsce w latach 1990-2003. Teoria i praktyka, AE Poznań, Poznań.

16. Patologie w bankructwach, 1993, „Rzeczpospolita”, Warszawa, B.II.

17. Stasiewski T., 1995, Upadek przedsiębiorstw przyczyny, symptomy i metody przewidywania, ZTRN, tom XXXIII.

18. Sudoł S., 2001, Przyczyny rozwoju i upadku polskich przedsiębiorstw przemysłowych w okresie transformacji gospodarczej lat 1990-2000, VII Kongres Ekonomistów Polskich, PTE, Warszawa, s. 9.

19. Szczerbak M., 2005, Przyczyny upadłości przedsiębiorstw w świetle opinii syndyków i nadzorców sqdowych [w:] K. Kuciński, E. Mączyńska, Zagrożenie upadłościq, SGH, Warszawa.

20. Zelek A., 2003, Zarzadzanie kryzysem w przedsiębiorstwie. Perspektywa strategiczna, Instytut Organizacji i Zarządzania w Przemyśle „ORGMASZ”, Warszawa.

21. www.coface.pl

\section{Bankruptcy as a Natural Regulator of Competition and Enterprise in Market Economy on the Basis of Polish Economy Analysis}

In the market economy you are never sure that your business will succeed. The is why the bankruptcy phenomenon activity is in a way, a natural regulator in an economic system which results in disappearance of enterprises being ineffective and unable to complete successfully. 